\title{
LET THE GAMES BEGIN: INSTITUTIONAL COMPLEXITY AND THE DESIGN OF NEW PRODUCTS
}

\author{
Raissa Pershina \& Birthe Soppe \\ Centre for Entrepreneurship, University of Oslo \\ 0318 Oslo, Norway \\ raissa.pershina@sfe.uio.no \\ birthe.soppe@sfe.uio.no
}

Forthcoming in Research in the Sociology of Organizations, Multimodality, Meaning, and Institutions, Vol.54A, 219-248

\begin{abstract}
This paper explores how organizations deal with divergent institutional logics when designing new products. Specifically, we investigate how organizations approach and embody institutional complexity in their product design. Through a multimodal study of serious games, we identify two design strategies, the proximity and the amplification strategies, which organizations employ to balance multiple institutional logics and design novel products that meet competing institutional expectations. Our paper makes an important theoretical contribution by showing how institutional complexity can be a source of innovation. We also make a methodological contribution by developing a new, multimodal research design that allows for the in-depth study of organizational artifacts. Altogether, we complement our understanding of how institutional complexity is substantiated in organizational artifacts and highlight the role that multimodality plays in analyzing such situations.
\end{abstract}

Keywords: institutional complexity; innovation; organizational artifacts; multimodality; serious games

\section{ACKNOWLEDGEMENTS}

The authors would like to thank Thibault Daudigeos, Mélodie Cartel, Sylvain Colombero, Eva Boxenbaum, Gregoire Croidieu, Aaron Horvarth, Davide Ravasi, Harald Reinertsen, Taran Mari Thune, the participants in the Copenhagen Business School workshop and seminars at the University of Oslo for their helpful suggestions. We would also like to thank the companies that kindly provided us with the screenshots of their games, and the experts and developers whom we interviewed for this study. 


\section{INTRODUCTION}

The topic of how organizations cope with institutional complexity has gained prominence among organizational scholars. Many types of organizations encounter institutional complexity in their efforts to create novel solutions to the challenges confronting society. Such organizations have to deal with multiple institutional logics and are exposed to divergent influences and prescriptions that may give rise to complex and ambiguous situations (Greenwood, Raynard, Kodeih, Micelotta, \& Lounsbury, 2011; Kraatz \& Block, 2008). Scholars have begun to investigate how organizations respond to institutional complexity by examining organizational strategies (Oliver, 1991), intra-organizational processes (Pache \& Santos, 2010), hiring policies (Battilana \& Dorado, 2010), governance forms (Battilana \& Lee, 2014; Pache \& Santos, 2013), and routine practices and negotiations at work (Battilana, Sengul, Pache, \& Model, 2015; Smets, Jarzabkowski, Burke, \& Spee, 2015). While the literature has significantly advanced our understanding of how organizations manage internally and externally such complex environments, research thus far has focused primarily on how divergent demands and identity struggles are being substantiated in organizational strategies, structures, and practices. Much less attention has been paid to organizational artifacts. Specifically, we know much less about how institutional complexity is instantiated in organizational products - one of the most visible organizational artifacts that are critical for an organization's reason for being. Products serve as a communication device between an organization and its diverse stakeholders, and particularly nascent product design has been shown to be of central importance in enhancing legitimacy and creating a market (Hargadon \& Douglas, 2001). We lack deeper insights into how organizations deal with divergent institutional logics when designing new products and how organizations approach and embody institutional complexity in their product design. Nevertheless, many organizations must frequently balance complex demands and divergent goals when developing products. Examples include brands seeking to create lines of clothes that are sustainable, fashionable as well as affordable, household goods producers attempting to design aesthetically appealing as well as highly functional goods (Dalpiaz, Rindova, \& Ravasi, 2016), and aerospace companies developing complex technological products in cooperation with academic, commercial, and governmental partners (Bergman, Lyytinen, \& Mark, 2007).

A substantial body of research has emphasized the conflicts that arise from operating under conditions of institutional complexity (e.g., Battilana et al., 2015; Glynn, 2000; Zilber, 2002). Yet, in contrast, a recently emerging stream of work has advanced a new view of institutional pluralism as the source of organizational innovation and an opportunity for value creation (Dalpiaz et al., 2016; Padgett \& Powell, 2012). We build on this recent line of scholarship and examine how organizations cope with institutional complexity when 
designing new products. In particular, we ask: How do organizations translate institutional complexity into innovative new products?

To address our research question, we conducted a qualitative study of the design of novel products, namely, serious games. Serious games are digital games developed for educational purposes. This empirical setting is particularly suitable for our study as serious games producers have to balance two distinct logics when designing the products: the logic of cultural production and the logic of effectiveness. While the former refers to serious games as a product of artistic creativity guided by the principle of play, the latter addresses professional concerns for pedagogical utility and business considerations. Moreover, most producers of serious games are entrepreneurial firms seeking to gain legitimacy and attract an audience for their novel products. Nascent entrepreneurs who design novel products and seek to create a market for them experience particularly strong complexities, as they often suffer from a liability of newness (Stinchcombe, 1965), the absence of a template for the product design (Hargadon \& Douglas, 2001), and ambiguous market situations (Santos \& Eisenhardt, 2009).

We approached this study by developing a multimodal research design and building a product database to examine in-depth the design of serious games and how they are an expression and embodiment of multiple institutional logics. Our study offers insights into how organizations balance and combine distinct logics to create new products. We identify two design strategies, proximity and amplification, which organizations employ to integrate and balance multiple institutional logics in a single product. Manipulating the conceptual distance between the logics (proximity strategy) and shifting the salience between them (amplification strategy) are two key strategies that allow product designers to manage logic tensions and channel them into novel product features. We explicate how combining conflicting institutional logics can be the source of product innovation. Second, we develop a new multimodal research design that allows for the in-depth analysis of products, decomposing them into their various modes. We highlight the importance of analyzing the ensemble of various modes and particular modal combinations to gain novel insights into the design of products. Altogether, we seek to complement our understanding of how institutional complexity is substantiated in organizational artifacts and to highlight the role that multimodality plays in analyzing such situations.

\section{THEORETICAL ORIENTATION}

Institutional complexity as a source of innovation 
Institutional logics are taken-for-granted, "socially constructed, historical patterns of material practices, assumptions, values, beliefs, and rules by which individuals produce and reproduce their material subsistence, organize time and space, and provide meaning to their social reality" (Thornton \& Ocasio, 1999, p.804). Organizations that harbor multiple logics under their roof often possess more than one identity, are bound to deal with conflicting normative orders, and have to address multiple external demands (Kraatz \& Block, 2008). Such organizations often experience institutional complexity, i.e. deeply rooted internal tensions (Greenwood, Díaz, Li, \& Lorente, 2010). Nevertheless, organizations that have to contend with multiple logics are common in many contexts, including social enterprises (Battilana \& Lee, 2014), academic entrepreneurship (Powell \& Colyvas, 2008), and family businesses (Miller, Le Breton-Miller, \& Lester, 2011).

Several studies have been conducted on the topic of institutional complexity, its impact on organizations, and the strategies organizations follow to respond to it. Much of this body of research has highlighted the incompatibilities, paradoxes, conflicts, tensions, and challenges that organizations encounter in attempting to straddle diverse institutional logics (Battilana et al., 2015; Zilber, 2002). For instance, the contestation between science and care has been shown to result in professional tensions among educators in medical schools (Dunn \& Jones, 2010). Similarly, Truelove and Kellogg (2016) found that differences between marketing and engineering can lead to severe power struggles when organizational contingencies change. To deal with such situations, the literature has suggested that organizations employ strategies such as defending and resisting conflicting demands or engaging in manipulation, avoidance, and contestation efforts (Oliver, 1991; Pache \& Santos, 2010). Collectively, this stream of research suggests that operating under conditions of institutional complexity absorbs managerial capacities and impedes the capacity to innovate.

However, an emerging body of scholarship on organizational innovation offers a more optimistic view, pointing out the positive aspects of combining seemingly conflicting institutional logics. Being exposed to multiple influences and complexities can be an important catalyst for innovation and an opportunity for new practices and value creation (Padgett \& Powell, 2012; Furnari, 2014). In order to combine elements and draw from multiple institutional contexts, actors must be able to creatively bridge and recombine knowledge, activities, capital, and ideas, allowing organizations to change, and to create new products and services (Reay \& Hinings, 2009; Stark, 2009). For example, institutional complexity has frequently been observed to be an engine of organizational change in architecture and publishing (Thornton, Jones, \& Kury, 2005), among medical professionals (Dunn \& Jones, 2010) and musicians (Glynn \& Lounsbury, 2005). Alessi, an Italian producer of household goods, intentionally melds the logics of manufacturing and cultural production to design innovative and creative products that enable the company to tap into new market 
opportunities (Dalpiaz et al., 2016). Furthermore, recombining multiple logics in novel ways can pave the way for innovation and result in the creation of new organizational forms. For instance, the early 1990s saw the logic of banking combined with the logic of social development to create a new type of commercial microfinance organization aimed at addressing the needs of the poor (Battilana \& Dorado, 2010). In order to tackle another pressing social issue - unemployment, a novel type of organization was created, namely, work integration social enterprises (WISEs), in which the social mission goes hand in hand with the goals of economic productivity (Battilana et al., 2015). Taken together, this recent stream of research suggests institutional complexity as an important source of innovation. Yet, we still know little about how organizations unleash the innovation potential inherent in situations of institutional complexity and translate it into innovative new outcomes. In other words, little is known about how institutional complexity is instantiated in products and other organizational artifacts, a topic to which we now turn.

\section{Organizational artifacts and institutional complexity}

It is only recently that organizational scholars have started to turn their attention to artifacts, and there is still much to be learned by analyzing them for organizational and institutional theorists (Jones, Boxenbaum, \& Anthony, 2013; Ravasi \& Stigliani, 2012). Organizational artifacts include logos and buildings, as well as more abstract concepts such as processes, professions and office jokes (Burkus, 2014). One of the most central artifacts of an organization is its product, which may be seen as a public statement by the organization (Rafaeli \& Pratt, 2006). A product is capable of evoking various emotions among an organization's audience, transforming stakeholders into co-creators and communicators of organizational meaning. Products represent the interface (Simon, 1981) between a company and its external constituents; products are intermediaries infused with institutional meaning. In the context of institutional complexity, products may also channel identity struggles and reflect competing external expectations.

Indeed, organizational artifacts have been shown to be an important site and expression of institutional logics. For instance, Christiansen \& Svejenova (2016), in their study of the Tiny House Movement, demonstrated how core ideas of environmental consciousness and lifestyle materialize in particular artifacts and design features of new home architecture such as simplicity and smaller spaces, recycled or sustainable construction materials, and multipurpose furniture. Jones, Maoret, Massa, \& Svejenova (2012) shed light on the role of various construction materials in the formation of modern architecture and how they served as material representations of competing logics. While modern architecture was experimenting with new styles and novel materials such as steel, concrete, and glass, revivalists were employing more traditional materials such as wood, brick, and stone. 
These and other studies call for more research on organizational artifacts and institutional complexity. Specifically, little research has focused on how divergent institutional logics can be integrated to give rise to a novel artifact such as a product. Previous studies have indicated the importance of balancing strategies at the organizational (Battilana \& Dorado, 2010) and individual levels (Smets et al., 2015) when dealing with divergent logics, but almost no research has considered how to achieve such a balance in the material dimension of organizational life, i.e. at the product level. We therefore have limited understanding of how diverse logics are instantiated in novel products. In this study, we investigate the design of new products under conditions of institutional complexity. In particular, we are interested in how organizations approach this complexity, how they balance distinct logics and translate them into new products.

\section{METHODOLOGY}

\section{Research setting}

We investigated the product design of digital games with serious purposes, also known as serious games. Serious games unite digital gaming and education and are used in a variety of fields, ranging from school and corporate training to healthcare and the military. Even though there are examples of non-digital serious games, in this study, we concentrated our efforts exclusively on the analysis of digital serious games. Digital serious games represent an ideal research setting for the purpose of our study. First, they represent a novel group of products that is currently emerging, for which no design templates yet exist. Most companies entering the market are startups and young firms.

Second, producers need to strike an optimal balance in designing their products, blending art and creativity involved in the design of traditional digital entertainment games with fulfillment of the product's primary goal - the learning objectives (Abt, 1970; Michael \& Chen, 2006; Sawyer, 2007). In other words, serious games organizations face the challenge of combining two distinct logics in the design of their digital artifact: the logic of cultural production and the logic of effectiveness. Both logics are integral, yet often competing aspects of the product's design. The logic of cultural production (Dalpiaz et al., 2016) is closely linked to the artistic pride of the game designers. The design of serious games relies heavily on expertise gained through the development of traditional digital entertainment games. These have recently been elevated to the rank of art and now officially belong to the sector of cultural and creative industries (Bliss de la Boissière, 2008; Flew, 2012). From this perspective, serious games are works of art as well as sources of professional pride that showcase the artistic mastery of their creators. Entertaining and amusing users is the primary goal (Dille \& Platten, 2007). In contrast, the logic of effectiveness refers to the games' educational utility and business considerations. From this point of view, serious games are professionl tools, rather than 
products of artistic creativity (Cruz-Cunha, 2012). They need to fulfill certain educational purposes and be effective in addressing consumer demands. While the logic of cultural production emphasizes the art and beauty of a game's process and the leisure and entertainment experienced by players, the logic of effectiveness focuses on the product's central purpose of delivering and measuring robust learning outcomes and educational functions that enable serious games to penetrate diverse target markets. Table 1 presents in more detail the two distinct logics that are involved in the design of serious games.

Table 1: Comparison of the logics of effectiveness and cultural production in serious games

Take in Table (1)

Developers of serious games face the challenge of trying to create feelings of freedom, fun, and excitement of a good video game, while simultaneously equipping it with the functions and features needed to fulfill its serious purpose of providing assessment of users' attainment of specific educative objectives. The literature on video games and serious games reflects this struggle. For example, some experts believe that once a game becomes serious, it ceases to be a game (Rockwell \& Kee, 2011). As part of this study, we conducted a range of interviews with game designers, game researchers, and serious games organizations. Many of our informants stated that it is indeed a great challenge to combine the various features required for the game's serious purpose with classical game elements. For example, one of our informants indicated that placing too much emphasis on learning effectiveness when designing the game would render the game boring, whereas focusing excessively on the entertainment aspects would result in a game that fails to fulfill its intended serious purpose. Specialists in learning assessment mentioned that the "flow" or the "zone" (Csikszentmihalyi, 2008), i.e. the feeling of full immersion and engagement, was a common topic of dispute when it came to integrating assessment features into the game. Overall, our interviews indicated that game designers are compelled to make compromises all the time. For instance, one game developer described his situation when designing a type of audio feedback, which was to be output whenever a certain game event occurred. The decision he faced was whether or not to prioritize an instructor's voice over funny and entertaining, but mostly incomprehensible noises generated by the game characters. Other interviewees described similar situations, citing examples involving the design of rewards, choosing game titles and characters, the appearance of game components, and decisions such as simplifying learning content in favor of coherent gameplay. Thus, integrating multiple logics into a single product is challenging. It puts developers in a position where they constantly have to balance multiple logics, while trying to make the product look coherent. This makes the process of designing serious games tricky and artful. 


\section{Sample}

We selected our sample of serious games from a pool of award-winning games and organizations to preclude the risk of collecting data from less "serious" games such as underdeveloped educational apps. Primary awards included in the selection process were two of the most prominent awards in the industry of serious games: "The Serious Play" and "Games for Change" awards. Drawing from the pool of awardwinning games, we constructed a dataset of more than 100 serious games developed since 2010. From this dataset, we randomly selected and analyzed a sample of 35 games. A detailed description of our sample is provided in Table A1 of Appendix A. The majority of the games were freely available through gamedeveloper websites, iTunes, and Google Play Store.

\section{Multimodal research design}

Given the explorative nature of our investigation, we chose a qualitative content analysis as our primary research method and developed a new, multimodal research framework to conduct an in-depth examination of the design of serious games. We opted for a multimodal research approach to uncover product design decisions in the very detail, at the level of the central modes of the product. This is the level where design decisions take place, and where multiple logics are put into effect. We consider multimodality to be the most suitable research approach for achieving the goals of this study, as it allowed us to trace micro design decisions which together shape complex digital products such as serious games.

No ready-to-use multimodal analytical framework for coding and analyzing serious games or similarly complex products exists. We developed such a coding tool by taking two main steps. First, we sought to understand the overall structure and main design areas of serious games. By interviewing game experts and reading game-design literature, we identified three important game dimensions, also known as the "game triangle", that refer to the three keystones of game design, namely: "Aesthetics", "Story", and "Gameplay". To deliver a high-quality gaming and learning experience, design decisions are often made across these three conceptual game dimensions. According to this structure, serious games are similar to ordinary entertainment games. However, the learning agenda affects the design of each of the three game dimensions. These three keystones represent the foundation of our multimodal research framework (Fig. 1).

Take in Figure (1)

Fig. 1: Conceptual structure of entertainment games 
In a second step, we identified the various modes that are associated with each of the three game dimensions, and how the two logics are displayed in the design of the modes. In other words, we decomposed the product into its various modes in order to be able to conduct a comprehensive and fine-grained product analysis. A mode is a resource for meaning making and is used for representation and communication (Kress, 2010). What is considered to be a mode is not fixed and depends on the context. According to Kress (2010), many different objects or phenomena can be interpreted as a mode, including images, videos, 3D objects, speech, or gestures. Serious games are complex multimodal products that include classical modes such as the visual (e.g., still and moving graphics), verbal (e.g., text fade-ins), and audio (e.g., voices of the game characters). However, in contrast to other multimodal products such as movies or journal articles, games are dynamic entities and also comprise modes related to interaction and game experience. Thus, for our multimodal framework, we focused not only on classical modes, but also on game-related modes, including characters, rewards, plots, interactive game components, and game systems, all of which were resources used to represent and communicate the story and the gameplay. They are also all crucial sites of the competition between the logic of cultural production and the logic of effectiveness. Analyzing how the two were balanced at the various modes enabled us to unravel in detail how organizations approach and embody institutional complexity in their product design.

To conduct this second step in building our multimodal coding framework, we examined the extensive body of game design literature, detected the most relevant modes associated with the three main game dimensions and how the two logics were balanced in design decisions at the modal level. Based on this, we built an initial basic coding scheme, which we then developed further and validated through several rounds of preliminary game analysis and ten interviews (with an average duration of 90 minutes) with designers of serious games, researchers, and founders of serious games companies. We also read and analyzed relevant archival data and documentation packages relating to the games in our sample. We summarize our multimodal coding framework in Figure 2, which depicts the three game dimensions and associated modes. In this Figure, we also integrated coding examples demonstrating how we coded for the logic of effectiveness at the level of each mode.

Take in Figure (2)

Fig. 2: Serious Game dimensions and associated modes, including coding examples

The identified modes serve as the level of analysis for our content analysis of serious games. Before turning to our data analysis, we explain in more detail what we mean by each specific game dimension and mode. 


\section{Aesthetics}

Aesthetics is a game dimension that is particularly considered when understanding games as art (Niedenthal, 2009). As was evident from our expert interviews, aesthetics provides a rich ground for debating how best to combine design elements embodying the logic of effectiveness with those embodying the logic of cultural production. In analyzing games as aesthetic artifacts, we paid particular attention to three modes: graphics (both still and moving), audio, and text. By graphics, we mean computer graphics used to display the content of serious games. Here, realism can be crucial for the logic of effectiveness, while stylization often adheres to the logic of cultural production. By audio, we mean game sounds, including sound effects, voiceovers, and background music. Voiceovers, for example, often comprise educational content. By text, we refer primarily to game and in-game titles and dialogues.

\section{Story}

The dimension of story grows out of an understanding of games as stories (Murray, 2004). Consequently, the most relevant modes associated with this game dimension include the plot and characters. The plot is an essential part of a game; it gives meaning to the players' actions. At the plot level, we coded, for example, for the presence of a story and several particularities such as its genre, the basis of its plot, and the inclusion of real-world concepts. At the character level, we explored both player and non-player characters and examined for the most part the characters' nature and their roles in the game to detect how the two logics were translated into design decisions.

\section{Gameplay}

This dimension reflects the view of games as abstract and formal systems (Tyler-Jones, 2013). The modes we paid most attention to in this dimension were the main systems, rewards, and mini-games. We examined assessment and feedback systems, and their integration with game-related features of the gameplay. Assessment is used to test and track students' progress, which is often a must-have feature in serious games. We were interested in how seamlessly assessment had been integrated in the gameplay. We also looked at rewards and how they were an expression of the two logics. Lastly, mini-games refer to games, often of different genres, that are integrated in the main gameplay or offered as part of the game package.

\section{Coding process and data analysis}

All of our sample games were coded and analyzed according to this multimodal research framework. To code a game, it was played for a minimum of 30 minutes and played in part again during subsequent coding rounds. Difficult coding decisions were discussed among the authors until agreement was reached. While coding the games, we collected screenshots and took detailed notes of the phenomena observed. Some of 
this we present as part of our illustrative material in this paper. In addition, we analyzed game documentation and teaching materials available on game developers' websites. The data was coded, stored, and analyzed using Microsoft Excel.

Overall, our qualitative content analysis can be characterized as hybrid, that is, a combination of deductive and inductive data analysis (Fereday, 2006). While one part of the process was based on our pre-designed and validated coding template (Crabtree \& Miller, 1992), another part was based on text analysis and theme development (Hsieh \& Shannon, 2005). Both of these coding steps were geared towards revealing, at the level of the modes, how the logics of cultural production and effectiveness were translated into design representations, and how the producer organizations dealt with tensions between the logics. For example, we detected that rewards in serious games can take the shape of traditional gaming rewards such as stars and fireworks (representing the logic of cultural production), they can be assessment-oriented such as certificates and statements of the achieved mastery level on a particular subject (representing the logic of effectiveness), or a combination of the two.

During the process of coding all our sample games, we identified communalities in the design decisions across the various modes. We noted all emerging design patterns and re-coded all our data one more time according to the strategies we had detected, which indicated how the two logics had been implemented. This process yielded the proposed design strategies that we present in the findings section. To ensure high reliability, we triangulated our findings through a second round of interviews in which we discussed our insights with the field informants, serious game experts, and practitioners.

\section{FINDINGS}

We identified two design strategies, which we labeled proximity and amplification. These are employed to recombine and balance competing institutional logics. In the following, we present these strategies along with illustrative examples from our coding of serious games. The full table of findings (Table 2) as well as illustrative pictures from the games can be found in the Appendix A.

\section{Proximity strategy}

Through our multimodal analysis of serious games, we detected a set of strategies, which we labeled "proximity strategy". By coding for the interplay between the logics in the design of the various modes of serious games, we noted three different degrees of proximity that mirror three related design approaches. 
We will now explain each of the three design approaches by providing illustrative examples across the various game dimensions and modes.

In general, the proximity strategy addresses how producers of serious games recombine, balance, and reconcile different logics when creating products. The working principle of this strategy lies in the interplay of the various degrees of proximity between the logics. It is the conceptual distance between the logics that differentiates the three design approaches, which we deem to be parts of this strategy.

\section{Hybridizing}

First, we detected a design approach that we labeled, in consultation with the literature on institutional complexity, hybridizing. Hybridizing represents a close degree of proximity between the logics and refers to instances in which two different logics are melted into a new amphibious element. We adopted this label following prior and related work, particularly a study conducted by York, Hargrave, \& Pacheco (2016), wherein the authors introduced hybridization as the integration of distinct goals through specific material forms, practices, and arrangements. We observed similar patterns in the designs of serious games across all game dimensions and modes.

Hybridizing seems to be a design approach that is frequently adopted to deal with multiple logics. For instance, we observed hybridizing in the design of game visuals such as still and moving graphics. According to the logic of effectiveness, there is sometimes a need to recreate the real world in digital format to fulfill a game's serious purpose. Realism, however, may often interfere with artistic vision and the logic of cultural production. Examples of games where realism matters include serious games that teach history, occupational games related to training in professional fields, and games that raise awareness about realworld issues and use realistic images and videos as evidence and emotional triggers. At the level of still and moving graphics, game designers hybridize when they combine 2D graphical elements with real-life pictures to form a single, novel element. Examples include the integration of a 2D character into a "real" crowd photographed in the early $20^{\text {th }}$ century ("Mission US: City of Immigrants") or the transition of a stylized video into a real life video ("Decisions That Matter") to underscore the point that issues raised in the game, while fictional, do indeed occur in the real world.

Other interesting cases of hybridizing can be found at the level of text. Here, we observed meaningful word plays that have been created based on the close interplay between the two logics. A particularly good example is the "Data Dealer" game, which raises awareness about issues in online privacy. In this ironic game, the player takes on the role of a data dealer who collects, connects, and sells the personal data of unsuspecting users. The player manages a social network platform named "Tracebook." They also mention "Smoogle." Both are oblique references to renowned online firms existing in real life. The wordplay should 
educate players about certain unlawful activities such as tracing and smuggling of online data, while at the same time preserving the entertaining nature of the game.

Audio represents another important site for hybridizing logics. An interesting design configuration is to use a sound that normally belongs to the realm of the logic of cultural production and utilize it to increase educational effectiveness. For instance, in "E-Learning for School Bus Drivers", music not only increases the entertaining value of the game experience, but at the same time serves as a learning tool by covering up the sound of an approaching train.

When it comes to the dimension of story, hybridizing is most visible at the level of the characters. Even in progressive learning tools such as serious games, novice learners or alias players will still need guidance (Gee, 2005). However, presenting too much of a teacher figure will render a game boring and decrease the transfer of the information learned via the character. To solve this conflict, game designers often create characters that have both an official role (e.g., a police officer) in the game and a hidden role as an instructor, i.e. someone who guides, assigns tasks and tests knowledge.

Regarding the dimension of gameplay, hybridizing happens when the game is designed in such a way that a certain system related to the logic of effectiveness becomes an integral part of the main gameplay. One such system is the assessment of learning. Games created for use in classrooms often have to address this formal requirement. Hybridizing is one way to handle this. Here, the assessment system is integrated into the game so that the tests look like another game challenge ("Gangs: PC 186.22 for Patrol for law enforcement").

\section{Composing}

Next, we identified a design approach that we labeled composing. Composing relates to cases in which the logics of cultural production and effectiveness are kept clearly separate, yet co-exist within the game. In such cases, the boundaries between the logics remain distinct, and both logics are preserved. Thus, similar to "compartmentalization", which can often be found in the literature (e.g., Pache \& Santos, 2013; Roccas \& Brewer, 2002), composing maintains the prescriptions of two logics as separate elements. However, composing differs from compartmentalization, as the prescriptions do not become isolated across time and space. Rather, composing signifies separation and co-existence. It refers to a medium degree of proximity between the two logics. While hybridizing units, composing balances and highlights multiplicity within an entity (Pratt \& Corley, 2012). As such, it covers the middle ground between hybridizing and decomposing (our third design approach).

Composing is especially common in text, such as in the naming of games. A carefully chosen name may constitute the meaning of the game and signal the game's identity to its audience. Examples of bringing 
together both logics while maintaining the fine line of separation are "Ratio Rumble" or "Ratio Rancher." The first word "Ratio" signals the learning objective of math ratios, whereas "Rumble" or "Rancher" defines the premise of the game — "to fight" in the first case and "to operate a ranch" in the second. Other interesting solutions include adding supplements such as "EDU" to the name of the game ("SimCity EDU") to signal both the educational mission and the entertaining concept of the game, or to separate parts that contain a different cognitive load with a dot ("Earth girl 2. Preparing for the tsunami”).

Regarding audio, composing refers to situations where the audio channel is used as a carrier of both logics, but they are each allocated their specific time during the gameplay. For instance, "At risk in Primary Care: Adolescent Version" features the instructor Amanda, who gives a brief lecture on the topic of adolescents and mental health before the main game begins. During this lecture, we see and hear Amanda. Later, however, after the main gameplay begins, her feedback and advice appear on the screen in a written format, while the audio channel plays the voices of the game characters.

In a similar manner, we observed composing within characters. Game designers compose when they present both educational instructor characters and characters related to the plot in a single game. In such cases, an instructor figure is clearly defined, and its educational role is clearly stated. Examples include teachers in "DragonBox Numbers" and "E-Learning for School Bus Drivers". Here, these characters are teaching assistants with the sole purpose of fulfilling an educational agenda. They co-exist, however, with other characters that have a role only within game stories.

Composing also occurs in designing systems for assessment, for example, when quizzes and tests are designed in a more traditional way and offered to the player as questions at the end of a task ("NOVA Evolution Lab") or at the end of a turn ("Practice Operations"). In all these instances, the learning assessment stands out clearly; it co-exists, but is explicitly separate from the main gameplay. Similarly, in the design of rewards, composing refers to games that present both output-oriented rewards such as educational certificates as well as gaming-related rewards such as stars and in-game resources.

\section{Decomposing}

The third design approach we detected through our coding is decomposing. Decomposing occurs when the two logics remain disconnected to such a degree that only one is represented within the game, whereas the other one exists outside of the game or, in extreme cases, is completely absent. In moderate instances, decomposing comes close to the mechanism of compartmentalization. In extreme instances, it mirrors the "deletion" concept proposed by Pratt \& Foreman (2000) in reference to the deliberate limitation of the number of organizational identities. Thus, decomposing occurs when the two logics are kept far apart, at a distant degree of proximity, and the game leans very heavily toward one institutional logic. 
For example, filling the audio channel exclusively with entertaining sounds such as music or sound effects is an illustration of extreme decomposing (“Argument wars"). An example of moderate decomposing would be detaching the assessment system from the main game, but preserving it in the game package by integrating questionnaires and tests into teaching materials available on the game's website ("Moonbase Alpha”), creating online pop quizzes ("Ratio Rumble”), or separate mini-games ("Thinking Fast! About The Past" - a testing mini-game for "Mission 4. City of Immigrants"). Some gaming experts think that equipping the gameplay with tests and learning routines "sucks the fun out" of them (Marsh et al., 2011, p.279); it makes games just another type of educational chore or "chocolate covered broccolis" (Mitgutsch \& Alvarado, 2012, p.124). At the same time, this formal system is of crucial importance for educational purposes and decision makers. Decoupling the assessment system from the main game and transforming it into lesson plans and quizzes available externally is one way to deal with this issue and to balance the tensions between the logics of cultural production and effectiveness. Decomposing as a design approach addresses exactly these types of situations.

\section{Amplification strategy}

Through our detailed coding of serious games, we have also observed that game producers employ certain amplification elements to cope with tensions between the logics of cultural production and effectiveness in the design of serious games. In particular, game developers utilize structural enrichments, emotions, and metaphors to "amplify" the two logics in serious games. While the proximity strategy substantiates institutional complexity through various forms of distance between the logics, the amplification strategy manipulates the saliency of the logics by boosting one logic or the other to prevent the product from slipping to either side. Amplification is therefore a strategy that also aids in recombining competing logics into an innovative product. We now present the three design approaches that are part of the amplification strategy.

\section{Structural enrichments}

Structural enrichments are one approach that product designers utilize to cope with institutional complexity and, by so doing, introduce new design elements. For example, in serious games, structural enrichments refer to mini-games, i.e. small games of a different genre that are designed as part of the main gameplay or part of the game. Playing them may be mandatory in order to advance in the main game ("Mission Biotech") or voluntary ("Plan it Green: The Big Switch"). Mini-games can present more learning-oriented material ("Mars Generation One: Argubot Academy EDU”) or purely entertaining additions ("Dex: Your Virtual Pet"). Mini-games, and structural enrichments more generally, are design elements that can tip the balance towards one logic or the other during the game by either conveying more learning-oriented material or 
being purely entertaining. Thus, structural enrichments are essentially novel design additions to the main product that can either amplify the logic of cultural production or the logic of effectiveness. While we accept that the concept of mini-games is limited to the world of digital gaming, the concept of adding novel ingredients in order to balance tensions across institutional logics could prove to be more universal and applicable to other empirical sites.

\section{Emotions}

Amplification through emotions is another design approach that we identified. Games as well as other types of art often comprise emotions (Lankoski, 2012). In serious games, emotions are used both to boost and to balance the entertainment experience and the educational effectiveness of the game.

While traditional types of education have little room for emotions, games can prompt people to laugh, cry, become angry, and/or get excited. Games provide limitless opportunities to evoke the gamut of emotions as a means of captivating the players' attention and deepening their engagement. On the other hand, affectively arousing events or information can create important contextual memory prompts, thus enhancing learning efficacy (Bower, 1992). There are also other benefits of involving emotions in education. Humor, for instance, is believed to improve the atmosphere for learning by lowering the pressure in a traditional school environment (Dormann \& Biddle, 2006). Thus, serious games seem to be a perfect arena for emotion-aided learning.

Amplification through emotions is a universal strategy that we detected across various modes. For instance, the appearance of the characters can be funny ("Game Over Gopher"), titles surprising ("NOVA Evolution Lab"), and texts amusing ("Ratio Rumble"). Even though one single game may stimulate a whole range of emotions, we found elements of drama and humor to be the most popular amplifications in serious games.

While the theme of emotions in the context of institutional complexity has not been extensively studied, emotional or "cathectic" orientation has been nominated as a candidate for the fourth pillar of institutionalization (Scott, 2001). In previous studies, scholars have shed light on emotional conflicts triggered in processes of identity work by institutional contradictions (Creed, DeJordy, \& Lok, 2010). Emotions of shame have been demonstrated to be a driver of peoples' commitment to institutional prescriptions (Creed, Hudson, Okhuysen, \& Smith-Crowe, 2014). Suddaby \& Greenwood (2005) revealed the role of emotions in rhetorical strategies to legitimate institutional change. Naturally, the topic of emotions is frequently linked to individuals as agents of change, even though emotions cover more aspects of institutional life (Creed et al., 2010). In the context of our study, we found that product designers employ emotions to relieve tensions between divergent institutional logics and by so doing, add novel and creative elements to the overall product. 


\section{Metaphors}

We also found that designers of serious games utilize metaphors in order to reconcile logics. Examples of metaphors include a sinking ship as a symbol for the federal budget ("The Fiscal Ship"), a software error as the mischievous blue monster "Glitch" ("The Foos"), or credit card debts represented by zombies ("Night of the Living Debt"). Metaphors in serious games are one way to design learning material in a playful and entertaining way. They serve as a pedagogical tool that helps to explain complex phenomena in easy terms and express thoughts more clearly and precisely (Boero, Bazzini, \& Garuti, 2001). Metaphors also trigger imagination, evoke aspects of surprise, and make the gaming-learning experience more engaging. Thus, we see the employment of metaphors as a way to nourish complementarities between logics and to facilitate their interplay.

\section{DISCUSSION AND CONCLUSIONS}

Our multimodal research strategy enabled us to gain deep insights into the design of serious games. In particular, we have showed how tensions between the logic of cultural production and the logic of effectiveness can be reconciled and how balancing divergent logics can catalyze innovative outputs.

\section{Summary of main findings}

We illuminated two main strategies of how organizations approach institutional complexity in the design of new products and translate such situations into innovative outcomes. First, we found a strategy we label proximity strategy. This strategy refers to situations in which developers of serious games allow an interplay between the divergent logics and, based on this, create new design elements across all modes and game dimensions. As part of this strategy, we detected three different degrees of proximity between the logics, which we present as three design approaches: hybridizing, composing, and decomposing. All three result in the creation of novel product features that literally embody institutional complexity.

Hybridizing refers to synthesizing and melting elements from two institutional domains to create one novel, amphibious element - an example of "blended worlds" (Murray, 2010). Having detected and analyzed the various instances of hybridizing in our setting, we want to add that this design approach generates the most innovative assembly of elements and arrangements, thus leading to the most novel and radical outcomes, which, in our context, are the most original and creative design decisions. Surprisingly, it was also the most commonly occurring design approach of all those we detected. This may be attributable to the circumstance that serious games are a novel group of products that requires a range of inventions to come into being. 
Also, our sample comprised the most successful, award-winning serious games and could therefore be expected to embody a high level of innovation.

Composing relates to situations in which institutional logics are brought into dialogue while also being kept separate, similar to "a form of coexisting worlds" as described by Murray (2010, p. 343), where logics neither blend nor collapse. Our analysis revealed that composing occurs when game developers try to preserve and balance the prescriptions of the two institutional logics. Thus, while hybridizing unites, composing balances and maintains complexities within a product. In the identity literature, composing resembles the concept of "aggregation" proposed by Pratt and Foreman (2000), who suggest that organizations aggregate when they seek to retain several identities while building conceptual links between them. In our context, composing applies to situations in which the logics of effectiveness and cultural production are kept separate, while the synergies between them are exploited. We found that not wholly new game elements are being invented; rather, novel connections between elements are being created.

Decomposing preserves both institutional logics, but keeps them clearly apart in the product package. In more radical instances, prescriptions of only one logic are followed, while the other logic becomes less important. By segregating the logics or giving a clear preference to one of them, decomposing can lead to interesting and novel design solutions.

Second, we found another strategy that we named amplification strategy. We observed that product designers employ three sets of amplifications - structural enrichments, emotions and metaphors - to cope with institutional complexity. By introducing these elements into the design of products, one of the two logics is amplified, and tensions between the divergent institutional logics are channelled into novel product features. For instance, structural enrichments such as mini-games enable product designers to integrate explicit educational content and assessment into games, making such enrichments efficient tools for amplifying the logic of effectiveness. However, mini-games may also provide an outlet for game designers' creativity and imagination, thus making them an equally successful tool for the logic of cultural production.

Emotions, even though they can be used strategically to create a memory prompt or to contextualize learning material, are first and foremost carriers of the logic of cultural production (Lankoski, 2012). Amplification through emotions is common design approach for making the overall experience of playing a serious game more entertaining, or for presenting a particular educational aspect in a more entertaining wrapping. However, emotions can also be used to amplify both logics and thus boost the overall gaminglearning experience. The utilization of emotions in product design has also been highlighted by Dalpiaz et al. (2016) in their study of Alessi, the Italian producer of household goods, which combined the logics of industrial manufacturing and cultural production in pursuit of new market opportunities. The authors show 
how Alessi used humorous and playful features and utilized emotions as a tool to reach younger people. We contribute to this stream of literature by highlighting the role of emotions in the context of institutional complexity. We demonstrate how amplification through emotions can be used to fine-tune the composition of the logics across various product dimensions, leading to the creation of innovative products.

Finally, we found that product designers amplify through metaphors. Earlier research devoted attention to the use of metaphors in the product design literature. In particular, metaphors have often been linked to creativity and shown to be a tool for enhancing creative designs (Hey, Linsey, Agogino, \& Wood, 2008; Wang \& Liao, 2009). We enrich this body of literature by presenting metaphors not only as a tool that contributes to the generation of creative output, but also as a tool for balancing conflicting logics.

Our findings offer interesting insights into the literature on institutional complexity, artifacts, and multimodality. We discuss these contributions below.

\section{Innovation and institutional complexity}

Our study offers insights into innovation activities under conditions of institutional complexity. In contrast to prior literature that has largely emphasized how institutional complexity creates organizational conflicts and impedes an organization's capacity to innovate, our study reveals two main strategies - the proximity and amplification strategies - that enable organizations to realize the creative potential inherent in situations of institutional complexity.

Building on the recent literatures on innovation (Padgett \& Powell, 2012; Furnari, 2014; Stark, 2009) and institutional complexity (Dalpiaz et al., 2016; Smets et al., 2015), we propose that institutional complexity is an important catalyst for innovation and a source of creativity and value creation. While the creation of new products in such complex settings is clearly challenging, we outlined a set of strategies that yield new design elements and together lead to the creation of innovative new products. As such, our study offers new insights on how the interplay between competing logics and their amplifications lead to the creation of novel products. While previous literature has alluded to strategies such as defiance, resistance, and avoidance of complexities, we have turned our attention to a new generation of strategies that emphasize the embracement of institutional complexity and the exploitation of the innovative potential inherent in such situations. Moreover, although previous research revealed a set of strategies for coping with institutional complexity, the prior body of work focused largely on strategies and consequences at the individual (Meyer \& Hammerschmid, 2006; Smets et al., 2015), organizational (Battilana \& Dorado, 2010; Pache \& Santos, 2013), and field levels (Glynn \& Lounsbury, 2005; York et al., 2016). We expand the study of institutional complexity to the product level. These efforts deepen our understanding of how 
organizations design products that draw from distinct institutional logics. Altogether, our study significantly expands our current understanding of innovation under conditions of institutional complexity, and we encourage future research to conduct further analyses at the product level.

\section{Artifacts and institutional complexity}

The role of organizational artifacts has only recently become a topic of scholarly attention in the literature on institutional logics. From this perspective, artifacts are the material representations of intangible institutional realms, "imbued with an institutional residue that shapes how artifacts are constructed, used, and understood" (Kaghan \& Lounsbury, 2006, p.2). In this paper, we studied the creation of institutionally complex artifacts.

Previous studies have demonstrated how artifacts play a significant role in sensemaking and evaluating products and organizations (Glynn \& Abzug, 2002; Glynn \& Marquis, 2006). This becomes especially salient with innovative new products. The pressure to reconcile competing parties and get the product design "right" is high and can have lasting implications. Organizations' ability to innovate despite institutional complexity and to productively translate tensions between institutional logics into novel design features may accelerate the acceptance of an innovation or its demise. Indeed, artifacts are symbols of collective identities and professions and are important markers for the granting of legitimacy. In particular, novel artifacts might be perceived as more legitimate if they are aligned with competing external expectations.

Jones et al. (2013) suggest that turning attention to the material aspects of institutional life is important in order to advance research on institutional logics. Our study follows this call by extending research on institutional complexity to the domain of organizational products. We propose that artifacts, including products, are an important site and expression of multiple and competing institutional logics and demonstrate the ways in which institutional complexity can be embedded in organizational artifacts. We identified two strategies that organizations employ in designing institutionally complex products, a process in which balancing the tensions between the inherent logics is critical for the creation of the overall product. Manipulating the conceptual distance between the logics (proximity strategy) and shifting the salience between them (amplification strategy) are two key strategies that may lead to the creation of products that effectively address divergent external expectations. 
Our paper also contributes to advances in multimodal research methods. To investigate in detail the strategies at play in the design of serious games, we developed and presented a new multimodal research framework. We did so by building on three primary game dimensions and the most relevant modes associated with each of them. Importantly, we departed from the traditional modes presented in the literature on multimodality and included other, non-traditional modes in order to adequately map the composition of serious games. This multimodal research approach enabled us to "get to the bottom" of the design of the games, to systematically code and compare the games, and eventually identify the various strategies used by developers of serious games to deal with the logics of cultural production and effectiveness.

An important element of our multimodal research technique, in analytical terms, was to interpret our findings by considering them across all modes, that is, the ensemble of the various modes. As such, the lens of multimodality not only helped us to go deep into the product's layers, but also enabled us to reveal the complex ensemble of elements involved in the design of the product and thus to capture the products' core identity. Our approach highlights the importance of analyzing the orchestration of various modes in addition to individual modes for gaining novel insights into the design of products. We consider modes also to be important carriers of institutional meaning, as we analyzed how the two distinct logics are implemented, i.e. how institutional complexity is substantiated within each of them.

We believe that our research framework can be extended to other areas of investigation of organizational artifacts. One interesting avenue for future research would be to investigate how entrepreneurs communicate their product innovations to the wider audience, for example, by using crowdfunding platforms. Here, entrepreneurs rely on text, video messages, pictures, drawings, and other modes to communicate the benefits and merits of their idea to the crowd. Another setting could be to explore how organizations present themselves and their products on their websites. Websites are a novel area of research of increasing attraction to organization scholars (Powell, Horvath, \& Brandtner, 2016), who may benefit greatly from a multimodal research design. Furthermore, multimodal analysis in the context of institutional complexity can be applied to other artifacts - those that have material substance (e.g., toys), or digital ones (e.g., edutainment shows for children). Another interesting area for future research could be to study movies and TV shows sponsored by brands, or video commercials. Here too, similarly to serious games, creative vision may interfere with the boundaries of a commercial agenda.

Our paper presents an early example of multimodality as a specific research technique that may be of great interest to other innovation and organization scholars since it affords deep insights into the social construction of organizational artifacts. Overall, multimodality may prove to be an indispensable tool for research not only on artifacts (Jones \& Svejenova, this volume), but also on organizations (Oberg, Drori, 
\& Delmestri, this volume), traditions (Croidieu, Soppe, \& Powell, this volume), and institutions (Jancsary, Meyer, Höllerer, \& Boxenbaum, this volume). 


\section{Appendix A}

Table A1: Descriptive game parameters

\begin{tabular}{|l|l|}
\hline Country & $\begin{array}{l}\text { US }(89 \%), \text { the rest (i.e., Norway, the UK, and Singapore) } \\
(11 \%)\end{array}$ \\
\hline Year & $2010-2015$ \\
\hline Overall purpose & $\begin{array}{l}\text { Academic subject }(46 \%), \text { Occupational (17\%), Raising } \\
\text { awareness }(14 \%), 21 \text { st world skills (14\%), Health }(6 \%), \text { and } \\
\text { Business }(3 \%)\end{array}$ \\
\hline Time to play & $\begin{array}{l}\text { Majority within 30 minutes (recommended time to play or } \\
\text { per case/session) }\end{array}$ \\
\hline Genre & Diverse, no dominant genre \\
\hline Type of graphics & $2 \mathrm{D}(66 \%)$ and 3D (34\%) \\
\hline Style of the game & Stylization (63\%), Naturalism $(26 \%)$, Abstract $(11 \%)$ \\
\hline Presence of characters & $89 \%$ \\
\hline
\end{tabular}

The percentage numbers (\%) are calculated on the basis of the total number of sample games (35).

Table A2: Findings: Three proximity design approaches in Serious Games

\begin{tabular}{|c|c|c|c|c|}
\hline Dimensions & Modes & Hybridizing & Composing & Decomposing \\
\hline \multirow[t]{2}{*}{ Aesthetics } & Graphics & $\begin{array}{l}\text { Realism in still and moving } \\
\text { graphics. } \\
\text { Examples: } \\
\text { "Mission 4. City of } \\
\text { Immigrants": } \\
\text { 2D faces are blended together } \\
\text { with real historical picture. } \\
\text { "Mission Biotech": Posters on } \\
\text { the wall that contain real-world } \\
\text { pictures. }\end{array}$ & $\begin{array}{l}\text { Realism in still and } \\
\text { moving graphics. } \\
\text { Examples: } \\
\text { "Manhattan ACE } \\
\text { Distribution Center } \\
\text { Basics": Realistic photo } \\
\text { inserts within 2D } \\
\text { gameplay. } \\
\text { "Ovie's engineering } \\
\text { challenge": The video of } \\
\text { a bear presented to } \\
\text { players at the end of the } \\
\text { first mission. }\end{array}$ & \\
\hline & & $\begin{array}{l}\text { Realism in icons and symbols. } \\
\text { Examples: } \\
\text { "E-learning for Bus drivers": } \\
\text { The bus control panel holds } \\
\text { recognizable realistic symbols, } \\
\text { as well as the road signs. } \\
\\
\text { "Practice Spanish: Study } \\
\text { Abroad": A fictional town } \\
\text { "Quyé" on a real map of } \\
\text { Colombia. }\end{array}$ & & \\
\hline
\end{tabular}




\begin{tabular}{|c|c|c|c|c|}
\hline Aesthetics & Audio & $\begin{array}{l}\text { Type I. } \\
\text { Different types of sounds } \\
\text { overlap with each other. } \\
\text { Example: } \\
\text { "Practice Spanish": Background } \\
\text { music overlaps with voiceovers. } \\
\text { Type II. } \\
\text { Sound effects or music serve } \\
\text { learning and entertaining } \\
\text { purposes simultaneously. } \\
\text { Example: } \\
\text { "E-Learning for School Bus } \\
\text { Drivers". }\end{array}$ & $\begin{array}{l}\text { Educational and } \\
\text { entertaining sounds co- } \\
\text { exist in the game and } \\
\text { have their own playing } \\
\text { time. } \\
\text { Example: } \\
\text { "E-Learning for School } \\
\text { Bus Drivers." }\end{array}$ & $\begin{array}{l}\text { Most games } \\
\text { have only } \\
\text { entertaining } \\
\text { types of sound. } \\
\text { In this case, the } \\
\text { educational } \\
\text { material and } \\
\text { instructions are } \\
\text { often provided } \\
\text { in a written } \\
\text { form. }\end{array}$ \\
\hline \multirow[t]{3}{*}{ Aesthetics } & \multirow[t]{3}{*}{ Text } & $\begin{array}{l}\text { Titles. } \\
\text { Examples: } \\
\text { "Quandary", "Superbugs." }\end{array}$ & $\begin{array}{l}\text { Titles. } \\
\text { Examples: } \\
\text { "DragonBox Numbers", } \\
\text { "SimCity EDU", "Martha } \\
\text { Madison. Optics". } \\
\end{array}$ & \\
\hline & & $\begin{array}{l}\text { Made-up words/ wordplay. } \\
\text { Examples: } \\
\text { "Data Dealer": Tracebook, } \\
\text { Smoogle. } \\
\text { "Mars Generation One: Argubot } \\
\text { Academy EDU": Argubots } \\
\text { named after argumentation } \\
\text { techniques: "Authoritron" - } \\
\text { quoting credible sources } \\
\text { (authority) to win arguments). } \\
\text { "Consebot"-using consequence } \\
\text { models - "if...then." }\end{array}$ & & \\
\hline & & $\begin{array}{l}\text { Content of dialogues. } \\
\text { Type I. Highlighted words } \\
\text { relevant to learning. } \\
\text { Examples by capital letters: } \\
\text { "Practice Operations", } \\
\text { "Quandary". } \\
\text { Examples by color or bold font: } \\
\text { "Gangs: PC } 186.22 \text { for Patrol", } \\
\text { "Mars Generation One: Argubot } \\
\text { Academy EDU". } \\
\text { Type II. Use of informal words. } \\
\text { Examples: } \\
\text { "Ovie's engineering challenge": } \\
\text { "Aw, shucks!" or "Uh oh!" }\end{array}$ & $\begin{array}{l}\text { Content of dialogues. } \\
\text { Using links to } \\
\text { educational material } \\
\text { within the game. } \\
\text { Examples: } \\
\text { "After the storm. } \\
\text { Community in Crisis", } \\
\text { "Mission 4. City of } \\
\text { Immigrants". }\end{array}$ & $\begin{array}{l}\text { Content of } \\
\text { dialogues. } \\
\text { Using links to } \\
\text { educational } \\
\text { material outside } \\
\text { of the game. } \\
\text { Example: } \\
\text { "Gangs: PC } \\
\text { 186.22 for } \\
\text { Patrol for law } \\
\text { enforcement". }\end{array}$ \\
\hline
\end{tabular}




\begin{tabular}{|c|c|c|c|c|}
\hline Story & Characters & $\begin{array}{l}\text { "Double agent" or hidden } \\
\text { instructor. } \\
\text { Examples: } \\
\text { "Ratio Rancher": a truck driver, } \\
\text { "Gangs: PC 186.22 for Patrol": } \\
\text { police officer, "Practice } \\
\text { Operations: director". }\end{array}$ & $\begin{array}{l}\text { Clearly stated instructor } \\
\text { in addition to NPCs. } \\
\text { Examples: } \\
\text { "At risk in Primary Care: } \\
\text { Adolescent Version", } \\
\text { "DragonBox Numbers". }\end{array}$ & $\begin{array}{l}\text { Only NPCs } \\
\text { related to story } \\
\text { or only } \\
\text { instructor. } \\
\text { Examples: } \\
\text { "Argument } \\
\text { wars", "Sim } \\
\text { City EDU". }\end{array}$ \\
\hline Story & Plot & $\begin{array}{l}\text { Type I. Existing learning } \\
\text { approach in the game. } \\
\text { Examples: "DragonBox } \\
\text { Numbers", "Argument wars," } \\
\text { "Enki". } \\
\text { Type II. Transforming existing } \\
\text { game into educational. } \\
\text { Examples: } \\
\text { "SimCity EDU", "Mission } \\
\text { Biotech" mini-game. }\end{array}$ & $\begin{array}{l}\text { Games that combine both } \\
\text { realism and elements of } \\
\text { fantasy but clearly } \\
\text { separate the two (e.g., by } \\
\text { grouping into various } \\
\text { chapters). } \\
\text { Example: } \\
\text { "Practice Spanish." }\end{array}$ & \\
\hline Story & Plot & $\begin{array}{l}\text { Use of concepts, organizations, } \\
\text { people, countries that exist in } \\
\text { real life. Introducing them from } \\
\text { real world into fictional stories. } \\
\text { Examples: "Fiscal Ship", "The } \\
\text { Underground Railroad: Journey } \\
\text { to Freedom". }\end{array}$ & & \\
\hline Gameplay & Rewards & & $\begin{array}{l}\text { Two types of rewards } \\
\text { present: gaming rewards } \\
\text { and certificates. } \\
\text { Examples: "Argument } \\
\text { Wars", "The Foos." }\end{array}$ & $\begin{array}{l}\text { Only gaming } \\
\text { rewards. }\end{array}$ \\
\hline Gameplay & Systems & $\begin{array}{l}\text { Assessment systems: Special } \\
\text { game challenges with the } \\
\text { purpose to test players" } \\
\text { knowledge or questions that are } \\
\text { naturally integrated in dialogues. } \\
\\
\text { Examples: "Mission Biotech", } \\
\text { "Gangs: PC } 186.22 \text { for Patrol". }\end{array}$ & $\begin{array}{l}\text { Assessment systems: } \\
\text { Questions that are given } \\
\text { to the player during the } \\
\text { game, between the levels, } \\
\text { or after a task. } \\
\text { Examples: "Practice } \\
\text { Operations". "E-Learning } \\
\text { for School Bus Drivers". }\end{array}$ & $\begin{array}{l}\text { Assessment } \\
\text { systems: } \\
\text { Questions that } \\
\text { are available } \\
\text { within } \\
\text { educator's } \\
\text { materials or as a } \\
\text { separate mini- } \\
\text { game. } \\
\text { Examples: } \\
\text { "Mission 4. } \\
\text { City of } \\
\text { Immigrants", } \\
\text { "Moonbase } \\
\text { Alpha". }\end{array}$ \\
\hline
\end{tabular}


Figures A1-A4: Coding illustrations from various game dimensions

Fig. A1: Hybridizing. Graphics: Realism and stylization
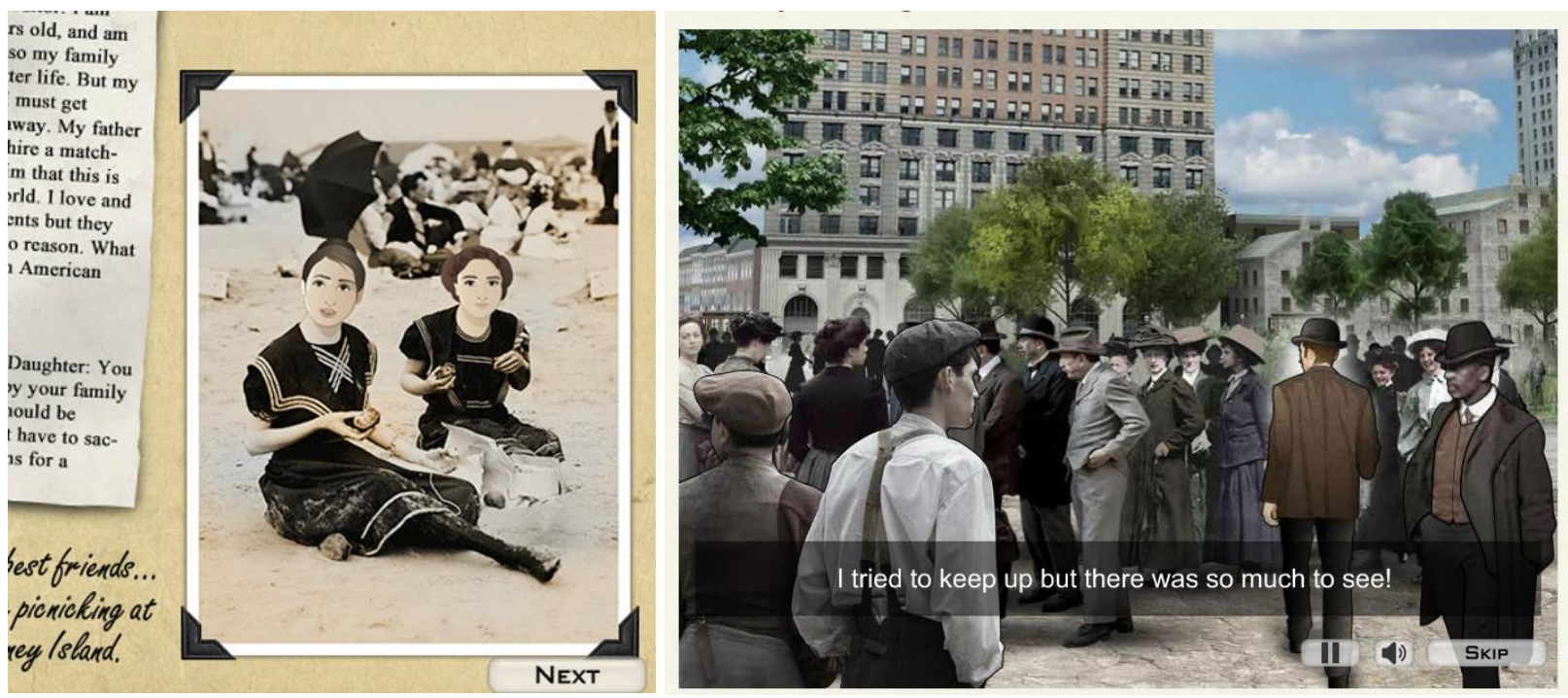

Fig. Ala: "Mission US: City of Immigrants". The 2D drawn faces of the main character (and her friend) replaced the faces in the picture taken in early $20^{\text {th }}$ century (middle); a 2D figure of a man incorporated into a historical picture (right). Produced by THIRTEEN Productions LLC in association with WNET. THIRTEEN Productions LLC.
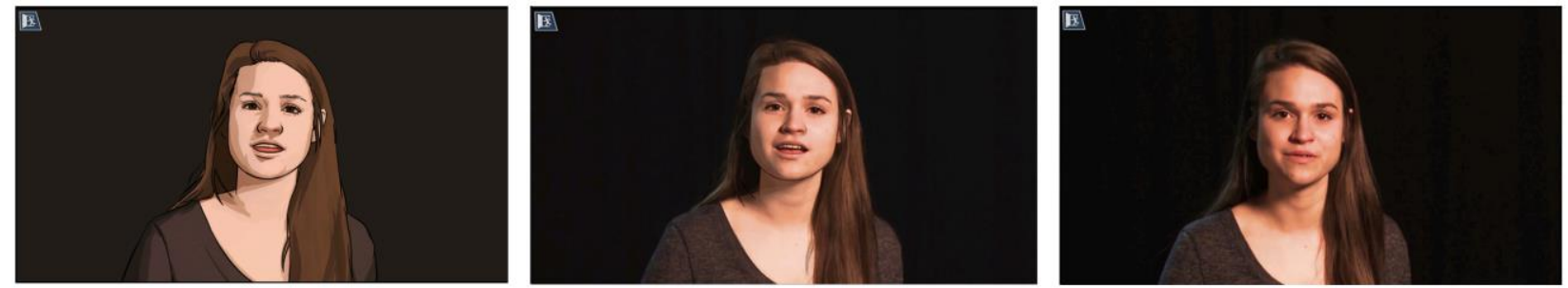

Fig. Alb: "Decisions that matter". Transition of a character from illustration to real-life video. Produced by Carnegie Mellon University's Dietrich College of Humanities and Social Sciences and Entertainment Technology Center (ETC). 
Fig. A2: Hybridizing. Made-up words

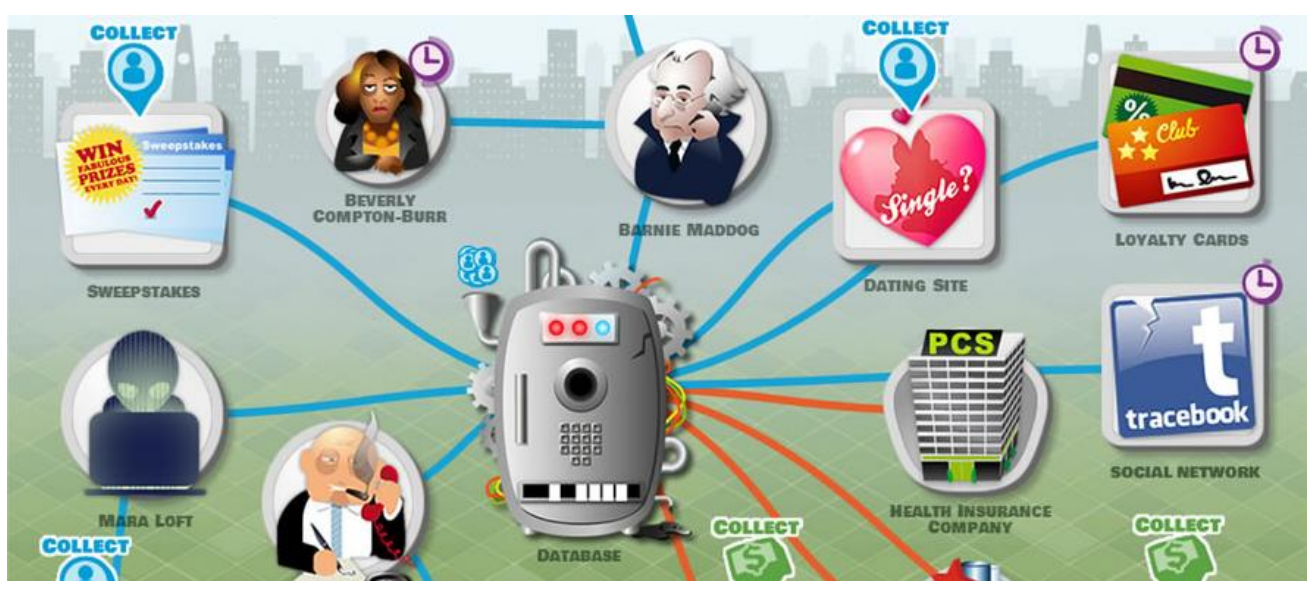

"Data Dealer". Players operate a social network “Tracebook" Produced by Ivan Averintsev, Wolfgang Christl, Pascale Osterwalder, Ralf Traunsteiner.

Fig. A3: Amplification through emotions
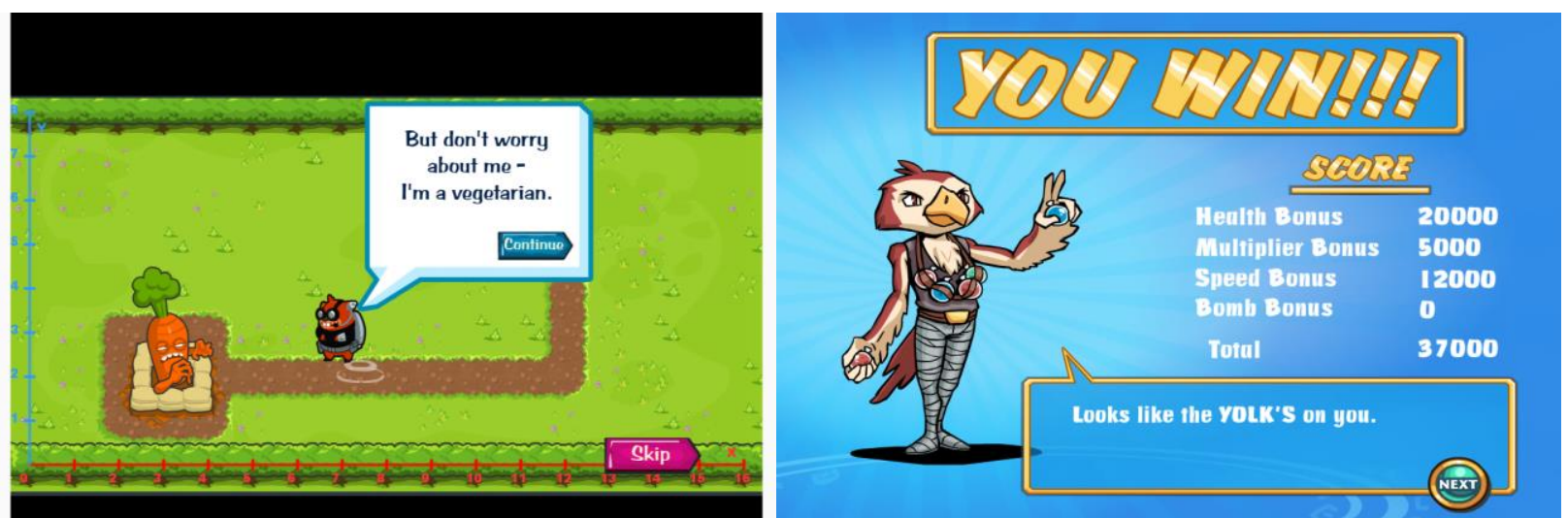

Examples of humor in serious games: "Game Over Gopher" (left), "Ratio Rumble" (right). Produced by The Learning Games Lab at New Mexico State University. 
Fig. A4: Amplification through metaphors

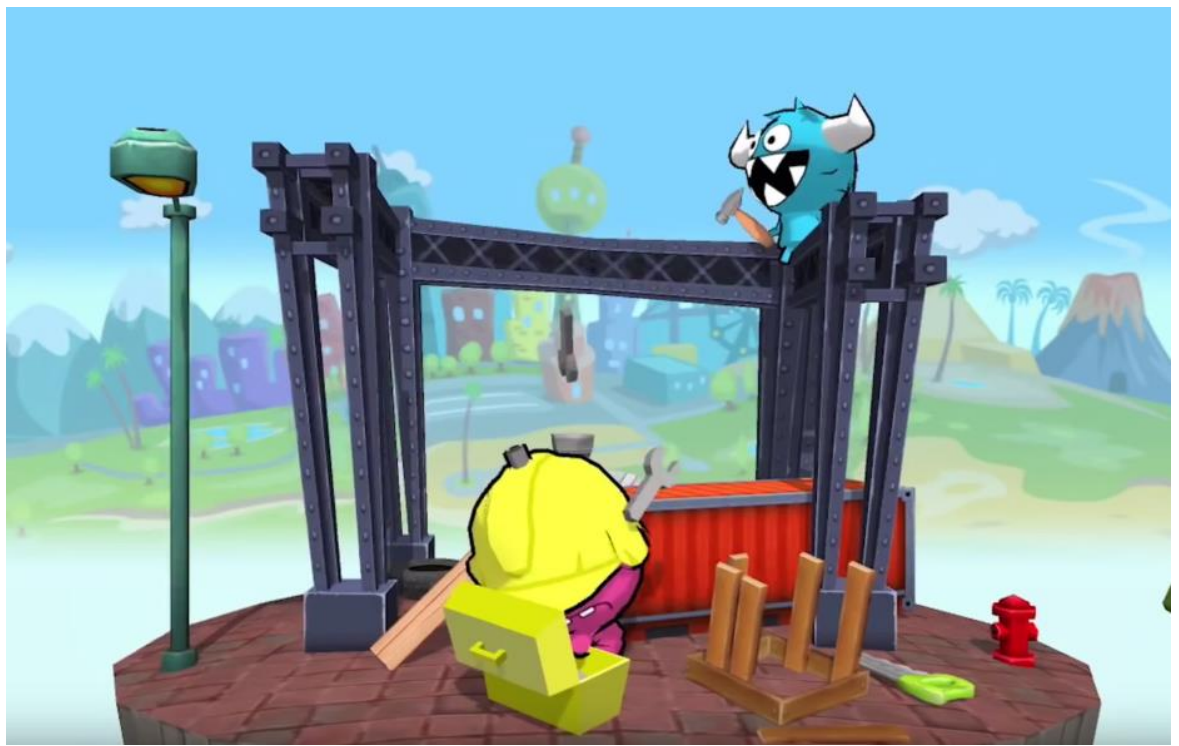

Examples of metaphor in serious games: "The Foos" (right) - "monster" Glitch as a computer program error. Produced by codeSpark. 


\section{REFERENCES}

Abt, C. C. (1970). Serious Games. New York: Viking Press.

Battilana, J., \& Dorado, S. (2010). Building sustainable hybrid organizations: The case of commercial microfinance organizations. Academy of Management Journal, 53(6), 1419-1440.

Battilana, J., \& Lee, M. (2014). Advancing research on hybrid organizing - insights from the study of social enterprises. The Academy of Management Annals, 8(1), 397-441.

Battilana, J., Sengul, M., Pache, A. C., \& Model, J. (2015). Harnessing productive tensions in hybrid organizations: The case of work integration social enterprises. Academy of Management Journal, 58(6), 1658-1685

Bergman, M., Lyytinen, K., \& Mark, G. (2007). Boundary objects in design: An ecological view of design artifacts. Journal of the Association for Information Systems, 8(11), 546-568.

Bliss de la Boissière, F. (2008, January). Video games: Officially art, in Europe. Gamasutra. Retrieved from https://www.gamasutra.com/view/feature/131929/video_games_officially_art_in_.php

Boero, P., Bazzini, L., \& Garuti, R. (2001). Metaphors in teaching and learning mathematics: A case study concerning inequalitites. Proceedings of the 25th annual meeting of the International Group for the Psychology of Mathematics Education, 185-192.

Bower, \& H., G. (1992). How might emotions affect learning? In S.-Å. Christianson (Ed.), The handbook of emotion and memory: Research and theory. Hillsdale, NJ: Lawrence Erlbaum Associates, Inc.

Burkus, D. (2014, December). How to tell if your company has a creative culture. Harvard Business Review. Retrieved from https://hbr.org/2014/12/how-to-tell-if-your-company-has-a-creative-culture

Christiansen, L. H., \& Svejenova, S. (2016). Institutionalizing collective identities through architecture: The Tiny House movement. Paper presented at the $12^{\text {th }}$ Workshop on New Institutionalism in Organization Theory.

Crabtree, B. F., \& Miller, W. F. (1992). A template approach to text analysis: Developing and using codebooks. Doing Qualitative Research, 3, 93-109.

Creed, W. E. D., DeJordy, R., \& Lok, J. (2010). Being the change: Resolving institutional contradiction through identity work. Academy of Management Journal, 53(6), 1336-1364.

Creed, W. E. D., Hudson, B. A., Okhuysen, G. A., \& Smith-Crowe, K. (2014). Swimming in a sea of shame: Incorporating emotion into explanations of institutional reproduction and change. Academy of Management Review, 39(3), 275-301.

Croidieu, G., Soppe, B., \& Powell, W.W. (forthcoming 2018). Cru, Glue, and Status: How wine labels helped ennoble Bordeaux. In M. A. Höllerer, T. Daudigeos, \& D. Jancsary (Eds.), Research on the Sociology of Organizations, 54(B). Emerald Group Publishing.

Cruz-Cunha, M. M. (Ed.). (2012). Handbook of research on serious games as educational, business and research tools. Hershey, PA: IGI Global.

Csikszentmihalyi, M. (2008). Flow: The psychology of optimal experience. New York, NY: Harper\&Row.

Dalpiaz, E., Rindova, V., \& Ravasi, D. (2016). Combining logics to transform organizational agency: Blending industry and art at Alessi. Administrative Science Quarterly, 61(3), 347-392.

Dille, F., \& Platten, J. Z. (2007). The ultimate guide to video game writing and design. New York, NY: 
Lone Eagle Publishing Company.

Dormann, C., \& Biddle, R. (2006). Humour in game-based learning. Learning, Media and Technology, 31(4), 411-424.

Dunn, M. B., \& Jones, C. (2010). Institutional logics and institutional pluralism: The contestation of care and science logics in medical education, 1967-2005. Administrative Science Quarterly, 55(1), 114149.

Fereday, J. (2006). Demonstrating rigor using thematic analysis: A hybrid approach of inductive and deductive coding and theme development. International Journal of Qualitative Methods, 5(1), 80-92.

Flew, T. (2012). The creative industries. Culture and policy. London, UK: SAGE Publications Ltd.

Frasca, G. (2003). Ludologists love stories, too: notes from a debate that never took place. In Digital Games Research Conference Proceedings.

Furnari, S. (2015). A cognitive mapping approach to business models: Representing causal structures and mechanisms. Advances in Strategic Management, 33, 207-239.

Gee, J. P. (2005). What would a state of the art instructional video game look like? Innovate: Journal of Online Education, 1(6), 1-5.

Girard, C., Ecalle, J., \& Magnan, A. (2013). Serious games as new educational tools: How effective are they? A meta-analysis of recent studies. Journal of Computer Assisted Learning, 29(3), 207-219.

Glynn, M. A. (2000). When cymbals become symbols: Conflict over organizational identity within a symphony orchestra. Organization Science, 11(3), 285-298.

Glynn, M. A., \& Abzug, R. (2002). Institutionalizing identity: Symbolic isomorphism and organizational names. Academy of Management Journal, 45 (1), 267-280

Glynn, M. A., \& Lounsbury, M. (2005). From the critics' corner: Logic blending, discursive change and authenticity in a cultural production system. Journal of Management Studies, 42(5), 1031-1055.

Glynn, M. A., \& Marquis, C. (2006). Fred's bank: How institutional norms and individual preferences legitimate organizational names. In M. G. Rafaeli, A., \& Pratt (Ed.), Artifacts and Organizations: Beyond Mere Symbolism (pp. 223-239). Mahwah, NJ: Lawrence Erlbaum.

Greenwood, R., Díaz, A. M., Li, S. X., \& Lorente, J. C. (2010). The multiplicity of institutional logics and the heterogeneity of organizational responses. Organization Science, 21(2), 521-539.

Greenwood, R., Raynard, M., Kodeih, F., Micelotta, E. R., \& Lounsbury, M. (2011). Institutional complexity and organizational responses. The Academy of Management Annals, 5(1), 317-371.

Hargadon, A., \& Douglas, Y. (2001). When innovations meet institutions: Edison and the design of the electric light. Administrative Science Quarterly, 46(3), 476-501.

Hey, J., Linsey, J., Agogino, A. M., \& Wood, K. L. (2008). Analogies and metaphors in creative design. International Journal of Engineering Education, 24(2), 283-294.

Hsieh, H.-F., \& Shannon, S. E. (2005). Three approaches to qualitative content analysis. Qualitative Health Research, 15(9), 1277-1288.

Jancsary, D., Meyer, R. E., Höllerer, M. A., \& Boxenbaum, E. (forthcoming 2018). How to draw an institution? Towards a structural analysis of visual and multimodal registers. In M. A. Höllerer, T. Daudigeos, \& D. Jancsary (Eds.), Research on the Sociology of Organizations, 54(A) Emerald Group 
Publishing.

Jones, C., Boxenbaum, E., \& Anthony, C. (2013). The immateriality of material practices in institutional logics. Research in the Sociology of Organizations, 39(A), 51-75.

Jones, C., Maoret, M., Massa, F. G., \& Svejenova, S. (2012). Rebels with a cause: Formation, contestation, and expansion of the de novo category "Modern Architecture," 1870-1975. Organization Science, 23(6), 1523-1545.

Jones, C., \& Svejenova, S. (forthcoming 2018). The architecture of city identities: A multimodal study of Barcelona and Boston. In M. A. Höllerer, T. Daudigeos, \& D. Jancsary (Eds.), Research on the Sociology of Organizations, 54(B). Emerald Group Publishing.

Kaghan, W. N., \& Lounsbury, M. (2006). Artifacts, articulation work and institutional residue. In M. G. Rafaeli, A., \& Pratt (Ed.), Artifacts and Organizations: Beyond Mere Symbolism (pp. 279-289). Mahwah, NJ: Lawrence Erlbaum.

Kraatz, M. S., \& Block, E. S. (2008). Organizational implications of institutional pluralism. In R. Greenwood, C. Oliver, K. Sahlin-Andersson, \& R. Suddaby (Eds.), The Sage handbook of organizational institutionalism (pp. 243-275). London, UK: Sage.

Kress, G. R. (2010). Multimodality: A social semiotic approach to contemporary communication. New York, NY: Routledge.

Lankoski, P. (2012). Computer games and emotions. In T. M. Sageng, J. R., Fossheim, H. J., \& Larsen (Ed.), The Philosophy of Computer Games (pp. 39-55). Netherlands: Springer.

Marsh, T., Nickole, L. Z., Klopfer, E., Xuejin, C., Osterweil, S., \& Haas, J. (2011). Fun and learning: Blending design and development dimensions in serious games through narrative and characters. In M. Minhua, A. Oikonomou, \& L. C. Jain (Eds.), Serious games and edutainment applications (pp. 273-288). London,UK:Springer.

Meyer, R. E., \& Hammerschmid, G. (2006). Changing institutional logics and executive identities: A managerial challenge to public administration in Austria. American Behavioral Scientist, 49(7), 10001014.

Michael, D., \& Chen, S. (2006). Serious games: Games that educate, train, and inform. Mason, OH: Thomson Course Technology.

Miller, D., Le Breton-Miller, I., \& Lester, R. H. (2011). Family and lone founder ownership and strategic behaviour: Social context, identity, and institutional logics. Journal of Management Studies, 48(1), 125.

Mitgutsch, K., \& Alvarado, N. (2012). Purposeful by design: A serious game design assessment framework. In Proceedings of the International Conference on the Foundations of Digital Games, FDG '12 (pp. 121-128).

Murray, F. (2010). The oncomouse that roared: Hybrid exchange strategies as a source of distinction at the boundary of overlapping institution1. American Journal of Sociology, 116(2), 341-388.

Murray, J. (2004). From game-story to cyberdrama. In N. Wardrip-Fruin \& P. Harrigan (Eds.), First Person. New Media as Story, Performance, and Game. Boston, MA: The MIT Press.

Niedenthal, S. (2009). What we talk about when we talk about game aesthetics. Technology, 9(July), 15.

Oberg, A., Drori, G. S., \& Delmestri, G. (forthcoming 2018). Where history, visuality and identity meet: 
Institutional paths to visual diversity among organizations. In M. A. Höllerer, T. Daudigeos, \& D. Jancsary (Eds.), Research on the Sociology of Organizations, vol. Multimodality, Meaning, and Institutions. Emerald Group Publishing.

Oliver, C. (1991). Strategic responses to institutional processes. Academy of Management Review, 16(1), $145-179$.

Pache, A. C., \& Santos, F. (2010). When worlds collide: The internal dynamics of organizational responses to conflicting institutional demands. Academy of Management Review, 35(3), 455-476.

Pache, A. C., \& Santos, F. (2013). Inside the hybrid organization: Selective coupling as a response to competing institutional logics. Academy of Management Journal, 56(4), 972-1001.

Padgett, J. F., \& Powell, W. W. (2012). The emergence of organizations and markets. Woodstock, Oxfordshire: Princeton University Press.

Powell, W. W., \& Colyvas, J. A. (2008). Microfoundations of institutional theory. In R. Greenwood, C. Oliver, R. Suddaby, \& K. Sahlin-Andersson (Eds.), The Sage handbook of organizational Institutionalism. Thousand Oaks, California: Sage.

Powell, W. W., Horvath, A., \& Brandtner, C. (2016). Click and mortar: Organizations on the web. Research in Organizational Behavior, 36, 101-120

Pratt, M. G., \& Corley, K. (2012). Managing multiple organizational identities: On identity ambiguity, identity conflict, and members reactions. In C. Bartel, S.L. Blader, \& A. Wirzesniewski, Identity and the modern organization (pp. 99-118). New York, NY: Psycology Press

Pratt, M. G., \& Foreman, P. O. (2000). Classifying managerial responses to multiple organizational identities. Academy of Management Review, 25(1), 18-42.

Rafaeli, A., \& Pratt, M. G. (2006). Artifacts and organizations: Beyond mere symbolism. Mahwah, NJ: Lawrence Erlbaum.

Rao, H., Monin, P., \& Durand, R. (2003). Institutional change in toque ville: Nouvelle cuisine as an identity movement in French gastronomy. American Journal of Sociology, 108(4), 795-843.

Ravasi, D., \& Stigliani, I. (2012). Product design: A review and research agenda for management studies. International Journal of Management Reviews, 14, 464-488.

Reay, T., \& Hinings, C. R. R. (2009). Managing the rivalry of competing institutional logics. Organization Studies, 30(6), 629-652.

Roccas, S., \& Brewer, M. B. (2002). Social identity complexity. Personality and Social Psychology Review, $6(2), 88-106$.

Rockwell, G. M., \& Kee, K. (2011). The leisure of serious games: A dialogue. Game Studies, 11(2).

Santos, F., \& Eisenhardt, K. (2009). Constructing markets and shaping boundaries: Entrepreneurial power in nascent fields. Academy of Management Journal, 52(4), 643-671.

Sawyer, B. (2007). Serious games: Broadening games impact beyond entertainment. Computer Graphics Forum.

Scott, W. R. (2001). Institutions and organizations. New York (Vol. 48). Thousand Oaks, CA: SAGE Publications.

Simon, H. A. (1981). The sciences of the artificial (2nd ed.). Cambridge, MA: MIT Press. 
Smets, M., Jarzabkowski, P., Burke, G. T., \& Spee, P. (2015). Reinsurance trading in Lloyd's of London: Balancing conflicting-yet-complementary logics in practice. Academy of Management Journal, 58(3), 932-970.

Stark, D. (2009). The sense of dissonance. Accounts of worth in economic life. Princeton, NJ: Princeton University Press.

Stinchcombe, A. L. (1965). Social structure and organizations. Advances in Strategic Management, 17(1), 229-259.

Suddaby, R., \& Greenwood, R. (2005). Rhetorical strategies of legitimacy. Administrative Science Quarterly, 50(1), 35-67.

Thornton, P. H., Jones, C., \& Kury, K. (2005). Institutional logics and institutional change in organizations: Transformation in accounting, architecture, and publishing. Research in the Sociology of Organizations, 23, 125-170.

Thornton, P. H., \& Ocasio, W. (1999). Institutional logics and historical contigency power in organizations. American Journal of Sociology, 105(3), 801-843.

Truelove, E., \& Kellogg, K. C. (2016). The radical flank effect and cross-occupational collaboration for technology development during a power shift. Administrative Science Quarterly, 61(4), 662-701.

Tyler-Jones, M. (2013, May). Ludology vs. narratology - the interpretation game. The Interpretation Game. Retrieved from https://memetechnology.org/2013/05/04/ludology-vs-narratology/

Voronov, M., De Clercq, D., \& Hinings, C. R. (2013). Institutional complexity and logic engagement: An investigation of Ontario fine wine. Human Relations, 66(12), 1563-1596.

Wang, H. H., \& Liao, W. J. (2009). Applications of metaphor theory to product design. In Proceedings of IASDR 2009 (pp. 18-22).

York, J. G., Hargrave, T. J., \& Pacheco, D. F. (2016). Converging winds: Logic hybridization in the Colorado wind energy field. Academy of Management Journal, 59(2), 579-610.

Zilber, T. B. (2002). Institutionalization as an interplay between actions, meanings, and actors: The case of a rape crisis center in Israel. Academy of Management Journal, 45(1), 234-254. 
Tables \& Figures

Table 1: Comparison of the logics of effectiveness and cultural production in serious games

\begin{tabular}{|c|c|c|}
\hline Characteristics & Logic of effectiveness $^{1}$ & Logic of cultural production $^{2}$ \\
\hline Mission and goals & $\begin{array}{l}\text { Delivering high-quality learning } \\
\text { outcomes and assessment. } \\
\text { Growing the client base and optimizing } \\
\text { the product development. } \\
\text { Designing efficient educational tools. }\end{array}$ & $\begin{array}{l}\text { Delivering leisure and entertainment. } \\
\text { Building game portfolios and a } \\
\text { professional artistic reputation. }\end{array}$ \\
\hline $\begin{array}{l}\text { Guiding principle } \\
\text { in the product } \\
\text { design }\end{array}$ & $\begin{array}{l}\text { Meeting the learning goals of a client. } \\
\text { Playing for the sake of learning } \\
\text { outcomes. } \\
\text { Emphasis on the outcome of the game. }\end{array}$ & $\begin{array}{l}\text { Creative vision. } \\
\text { Playing for the sake of play. } \\
\text { Emphasis on the process of the game. }\end{array}$ \\
\hline Product identity & $\begin{array}{l}\text { Games as tools to reach learning goals. } \\
\text { Game design as a source of sustainable } \\
\text { turnover through the process of } \\
\text { creating effective learning tools. }\end{array}$ & $\begin{array}{l}\text { Games as art and source of artistic } \\
\text { pride. } \\
\text { Game design as craft. } \\
\text { Values and beliefs revolving around } \\
\text { originality, creativity, and artistic } \\
\text { freedom. }\end{array}$ \\
\hline Target audience & $\begin{array}{l}\text { Products should successfully meet the } \\
\text { "serious needs" of decision makers and } \\
\text { business managers who see serious } \\
\text { games as a source of higher turnover } \\
\text { and who expect proven learning } \\
\text { outcomes and specific educational } \\
\text { product features. }\end{array}$ & $\begin{array}{l}\text { Products should provide a high quality } \\
\text { gaming experience to end users who } \\
\text { expect entertainment and fun. }\end{array}$ \\
\hline Focus of attention & $\begin{array}{l}\text { Functions and features of the product } \\
\text { that provide evidence of teaching } \\
\text { effectiveness and that enable successful } \\
\text { product integration into clients' training } \\
\text { routines. }\end{array}$ & $\begin{array}{l}\text { Form of the product with an emphasis } \\
\text { on creating games with original } \\
\text { gameplays and creative novel stories. }\end{array}$ \\
\hline
\end{tabular}

\footnotetext{
${ }^{1}$ We detected this logic based on extensive research of the serious games literature (e.g., Cruz-Cunha, 2012; Girard, Ecalle, \& Magnan, 2013) and in-depth interviews with industry experts. We also triangulated our findings with comparable studies on commercial and market logics (e.g., Glynn \& Lounsbury, 2005; Pache \& Santos, 2013). ${ }^{2}$ We detected this logic based on extensive research of the video game literature (e.g., Dille \& Platten, 2007), indepth interviews with industry experts, and triangulation with previous studies on the logics of cultural production (e.g., Dalpiaz et al., 2016; Glynn, 2000; Thornton et al., 2005; Voronov, De Clercq, \& Hinings, 2013).
} 
Figure 1: Conceptual structure of entertainment games

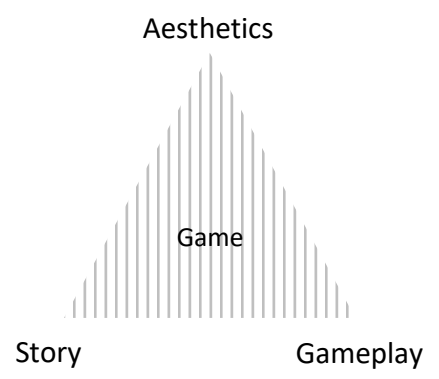

Figure 2: Serious game dimensions and associated modes, including coding examples

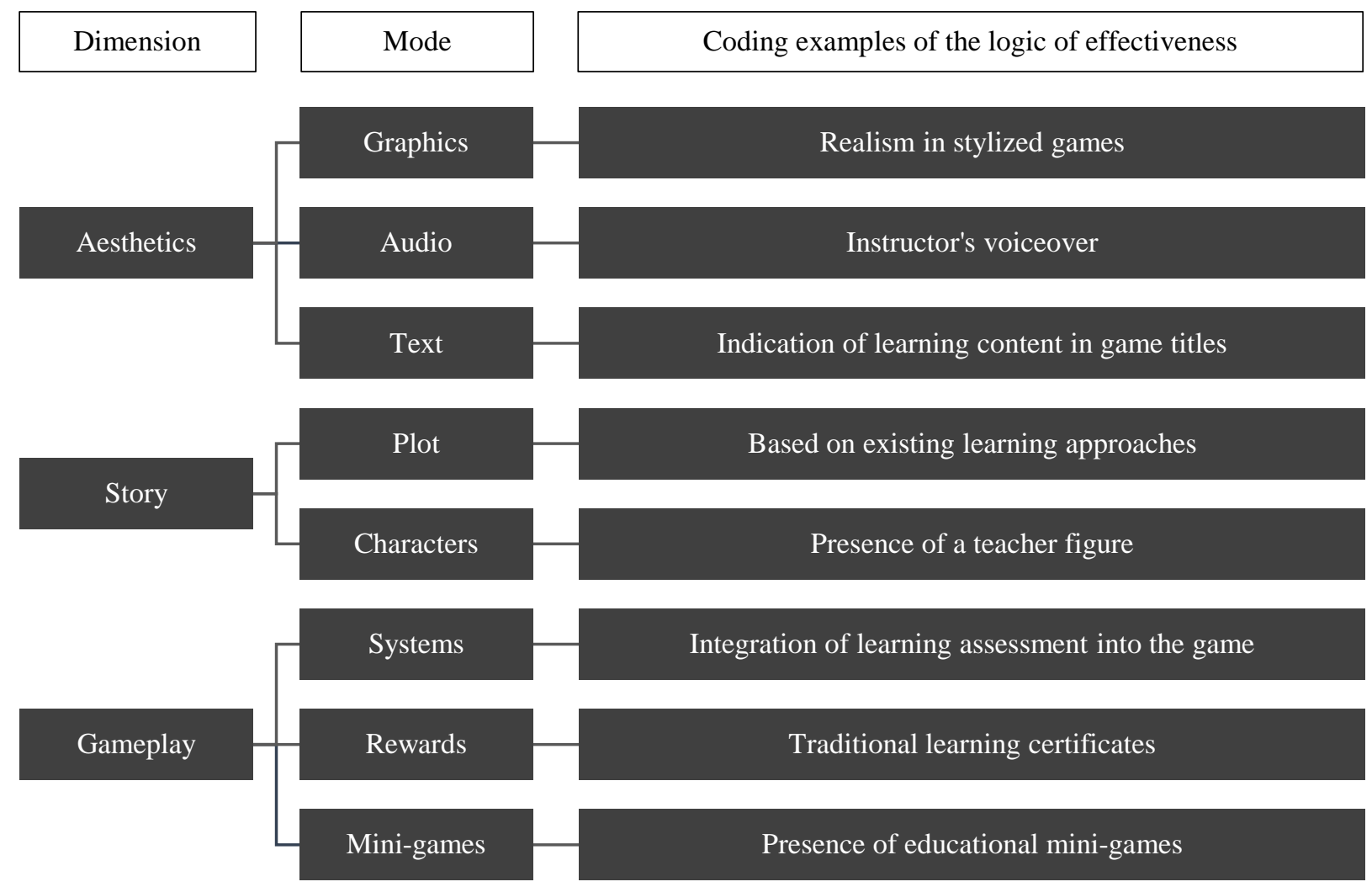

